\title{
Comparison of the Physico-chemical Properties of Shark Skin Collagen and of Pig and Bovine Skins
}

\author{
Keiji YOSHIMURA, Daiki HOZAN, Yasumasa CHONAN \\ and Kunio SHIRAI* \\ Tokyo Metropolitan Leather Technology Center, \\ Sumida-ku, Tokyo 131 \\ * Faculty of Agriculture, Tokyo University of Agriculture \\ and Technology, Fuchu-shi 183
}

(Received November 21, 1995)

\begin{abstract}
Collagen fibrillar network and physico-chemical properties including the reactivity of functional groups, swelling properties and thermal characteristics determined by differential scanning calorimetry of shark (Great Blue Shark) skin collagen were compared with those of pig and bovine skins. Observation on scanning electron microscope results showed that the significant features of shark skin were the looser and thinner collagen fibrillar bundles in the middle layer of corium composing the main part of skin. The total uronic acid content in shark skin collagen was the largest, while its fraction extracted with a neutral buffer solution was the smallest. This suggested that shark skin collagen associates with proteoglycans more strongly than other kinds of collagen. From pH-titration curves, no significant difference in the maximum combined amount of hydrogen and hydroxyl ions among the three kinds of collagens was observed and the combined amount in neutral and weak acidic $\mathrm{pH}$ regions was larger for shark skin collagen than for the other collagens. Shark skin collagen exhibited a strong swelling ability, especially in the acidic $\mathrm{pH}$ region. There was no difference in the denaturation temperature at various $\mathrm{pH}$ between pig and bovine skin collagen, while shark skin collagen exhibited a significantly lower denaturation temperature, with a certain degree of rise in the denaturation temperature in alkaline region.
\end{abstract}

Anim. Sci. Technol. (Jpn.) 67 (5) : 445-454, 1996

Key words : Collagen, Skin, Shark, Swelling, Thermal stability

Animal skins have been long used as raw materials for leathers, furs, gelatins and other products. In recent years, their collagens in the native form are also widely used in different fields including foods as well as biochemical uses such as cosmetics, medical material and cell cuiture technology $y^{2,10,18)}$. Such growing demands for collagen make it natural to have a more diverse range of functionality. Collagen from domestic animals like bovines and pigs are usually used in industries and they are chemically modified using proteases, crosslinking agents and other reagents to vary and control their function for respective uses $^{7}{ }^{70)}$.

Inherent difference in characteristics among collagen species should be considered. The possible range of diversification by chemical modification varies depending on the species of collagen used. As collagen species classified in type I include a group of collagens that are different in molecular level depending on 
animal species, it is important to classify the kinds of distinguish collagens in different animal species not only for leather manufacture but also for collagen biochemical industries.

In the described background, the authors paid attention to shark (Great Blue Shark) skin collagen as a potentially important material in terms of the quantity and quality of the product. Kimura et al. ${ }^{123}$ reported that although Great Blue Shark skin collagen has the molecular features common to those of land animals, its peptide constitution is significantly different from those of land animals. Much remains, therefore, to be clarified on the characteristics of shark skin collagen. Furthermore, from the viewpoint of utilization of collagen, it is important to investigate insoluble collagen which composes the dominant part of the collagen tissue. In the present paper, the physicochemical properties of shark skin collagen fibers were compared with those of pig and bovine origins.

\section{Materials and Methods}

Preparation of Collagen Cubes (Skin Tissue Specimens) :

Pig ( 3 Landrace, $6 \mathrm{~kg} /$ piece of skin) and bovine (2 Japanese Black steer, $25 \mathrm{~kg} /$ piece of skin) skins were purchased from the Central Wholesale Market in Tokyo. Their collagen cubes (pig and bovine collagen cubes are abbreviated as $\mathrm{PC}$ and $\mathrm{BC}$, respectively) were prepared from fresh skin corium as described in the previous paper ${ }^{24)}$. However, extraction to remove acid soluble collagen was omitted because it could affect the swelling ability of collagens. Pig or bovine skin corium was cut into $5 \mathrm{~mm} \times 5 \mathrm{~mm} \times 5 \mathrm{~mm}$ cubes and extracted with acetone, $\mathrm{n}$-hexane, $10 \% \mathrm{NaCl}$ soln., $1 / 15 \mathrm{M}$ phosphate buffer at $\mathrm{pH} 8.0$ in series. The cubes were then thoroughly washed with distilled water and finally freeze-dried to give collagen cube samples.

Shark skin collagen cubes (SC) in $5 \mathrm{~mm} \times 5$ $\mathrm{mm} \times 5 \mathrm{~mm}$ were prepared from Great Blue Shark (10 pieces of skins) corium as described by Kubota $e t a l{ }^{14)}$. The skin was freshly collected from sharks unloaded at Kesennuma port and transported to the laboratory in the frozen state. The cubes were extracted with acetone, $\mathrm{n}$-hexane and $0.5 \mathrm{M}$ sodium acetate in series. The cubes were thoroughly washed with distilled water and then freeze-dried to give collagen cube samples. All the operations were conducted in a room temperature at $4^{\circ} \mathrm{C}$.

Preparation of collagen powder:

Freeze-dried collagen cubes were crushed in a freeze-crusher (Ti-500 DX, CMT) under cooling with dry ice. The crushed material was passed through a $100-$ mesh sieve. The fraction was collected and referred to as collagen powder samples. Shark, pig and bovine collagen powders are abbreviated as SP, PP, and BP, respectively.

Observation of collagen fiber structure by scanning electron microscopy (SEM) :

SEM specimen was prepared by alkaline maceration of skin tissue according to Ohtani's method $^{20,21)}$. The specimen was dehydrated in a series of graded concentration of ethanol, and dried in a HCP-2 (Hitachi) critical point dryer using liquid $\mathrm{CO}_{2}$. The dried specimen was mounted on metal stubs with a double face adhesive tape, coated with gold by ion sputtering, and observed under SEM (JSMT300, JEOL) with an accelerating voltage of 10-15 $\mathrm{kV}$.

\section{Amino acid analysis :}

Collagen cubes were hydrolyzed in $6 \mathrm{~N} \mathrm{HCl}$ at $110^{\circ} \mathrm{C}$ for 24 hours and their amino acid compositions were determined in an amino acid analyzer (JLC-300, JEOL).

Determination of extracted uronic acid :

Two grams of collagen cubes were stirred in $100 \mathrm{~m} l$ of $0.02 \mathrm{M}$ Tris- $\mathrm{HCl}$ buffer solution $(\mathrm{pH}$ $7.0)$ at $4^{\circ} \mathrm{C}$ for $48 \mathrm{hr}$. The suspension was centrifuged at $18,000 \mathrm{rpm}$ for 20 minutes at $4^{\circ} \mathrm{C}$. The supernatant was used for protein and 
uronic acid analysis. The residue was further stirred in $100 \mathrm{~m} l 0.5 \mathrm{M}$ guanidine hycrochloride in $0.02 \mathrm{M}$ Tris- $\mathrm{HCl}$ buffer solution ( $\mathrm{pH} 7.0$ ) for 48 hr. The suspension was centrifuged at 18,000 rpm for 20 minutes. The supernatant was analyzed for its protein and uronic acid contents. The ratio of uronic acid per protein content was used as indicator of glycosaminoglycan.

Protein and uronic acid contents were determined by the microbiuret method ${ }^{11)}$ and the sulfuric acid-carbazole method ${ }^{3)}$, respectively. The calibration curve was prepared using acid soluble collagen and glucuronic acid.

SDS-polyacrylamide gel electrophoresis (SDS$P A G E)$ :

SDS-PAGE was carried out by the methods of Laemmli ${ }^{16)}$ and Hayashi and Nagai ${ }^{9)}$. Collagen cubes were heated at $100^{\circ} \mathrm{C}$ for five minutes in $0.0625 \mathrm{M}$ Tris- $\mathrm{HCl}$ buffer solution at $\mathrm{pH} 6.8$ containing $3.6 \mathrm{M}$ urea, $2 \%$ SDS and $20 \%$ glycerol. The dissolved fraction was applied on 5\% slab-gel. Protein band was stained with Coomassie Brilliant Blue.

\section{pH-titration curves :}

An automatic titrator (COMTITE-900, Hiranuma) was used to obtain $\mathrm{pH}$-titration curves of collagen powder. Collagen powders (250 $\mathrm{mg}$ ) were dispersed in $45 \mathrm{~m} l$ of $0.05 \mathrm{M} \mathrm{NaCl}$ solution and left at $4^{\circ} \mathrm{C}$ for one hour. Nitrogen gas was passed into the solution at $60 \mathrm{kPa}$ for 40 minutes to remove carbon dioxide. The mixture was automatically titrated with $0.1 \mathrm{~N}$ $\mathrm{NaOH}$ standard solution containing $0.05 \mathrm{M}$ $\mathrm{NaCl}$ or $0.1 \mathrm{~N} \mathrm{HCl}$ standard solution containing $0.05 \mathrm{M} \mathrm{NaCl}$. Titration was done at $20^{\circ} \mathrm{C}$. Standard titration curve was determined separately for the solvent alone, and the curves of $\mathrm{pH}$ of combined $\left[\mathrm{H}^{+}\right]$or $\left[\mathrm{OH}^{-}\right]$were done using the procedures of Bowes and Kenten ${ }^{4}$.

\section{Swelling ability :}

Fifty milligrams of collagen cube samples was equilibrated with $5 \mathrm{~m} l$ distilled water at $4^{\circ} \mathrm{C}$ for $24 \mathrm{hr}$. Then, $5 \mathrm{ml} \mathrm{HCl}$ or $\mathrm{NaOH}$ solution of a different concentration was added to the sample, kept at $4^{\circ} \mathrm{C}$ for $48 \mathrm{hr}$ and the mixture was centrifuged at $4,000 \mathrm{rpm}$ for 15 minutes. The $\mathrm{pH}$ was measured. The residue was weighed to determine measured the amount of the sorbed water per gram of dry collagen cube. The protein content in the supernatant was measured and used to correct the error due to the dissolved collagen.

DSC (differential scanning calorimetry) measurement :

DSC of collagen cube samples were performed using a DSC (DSC 120 with a data processing system SSC 5200 , Seiko) as described by Takahashi et al. ${ }^{28\rangle}$. From DSC measurement, denaturation temperatures [onset temp (To) and peak temp (Tp)] were recorded as characteristics of the denaturation process.

\section{Results and Discussion}

\section{SEM observation :}

As shown in Fig. 1, the SEM of each skin revealed different features. Characteristic scales are shown on the surface of shark skin (Fig. 1 A). It has been reported that collagen fibrillar bundles of fish skin diagonally crossing over to each other parallel to the surface so that a characteristic layer structure was observed across the entire cross section of the corium $^{29)}$, but such structure in Great Blue Shark skin was observed only in the upper and bottom layer of corium but not shown in middle (Fig. 1 A, 2). Collagen fibrillar bundles of bovine skin are thinner than shark and pig skin in the upper layer of corium (Fig. $1 \mathrm{~B}, \mathrm{E}, \mathrm{H}$ ). However, collagen fibrillar bundles of shark skin were looser and thinner than those of pig and bovine skins in the middle layer of corium composing the main part of skin (Fig. 1C, F, I). It was demonstrated that thickness of collagen fibrillar bundles in this layer decreased in the order of bovine $>$ pig $>>$ shark.

Amino acid composition and SDS-PAGE :

Although values of half cystine $(2 / 1000$ residues) for shark and pig preparations indicated a small degree of epidermal tissue contamina- 

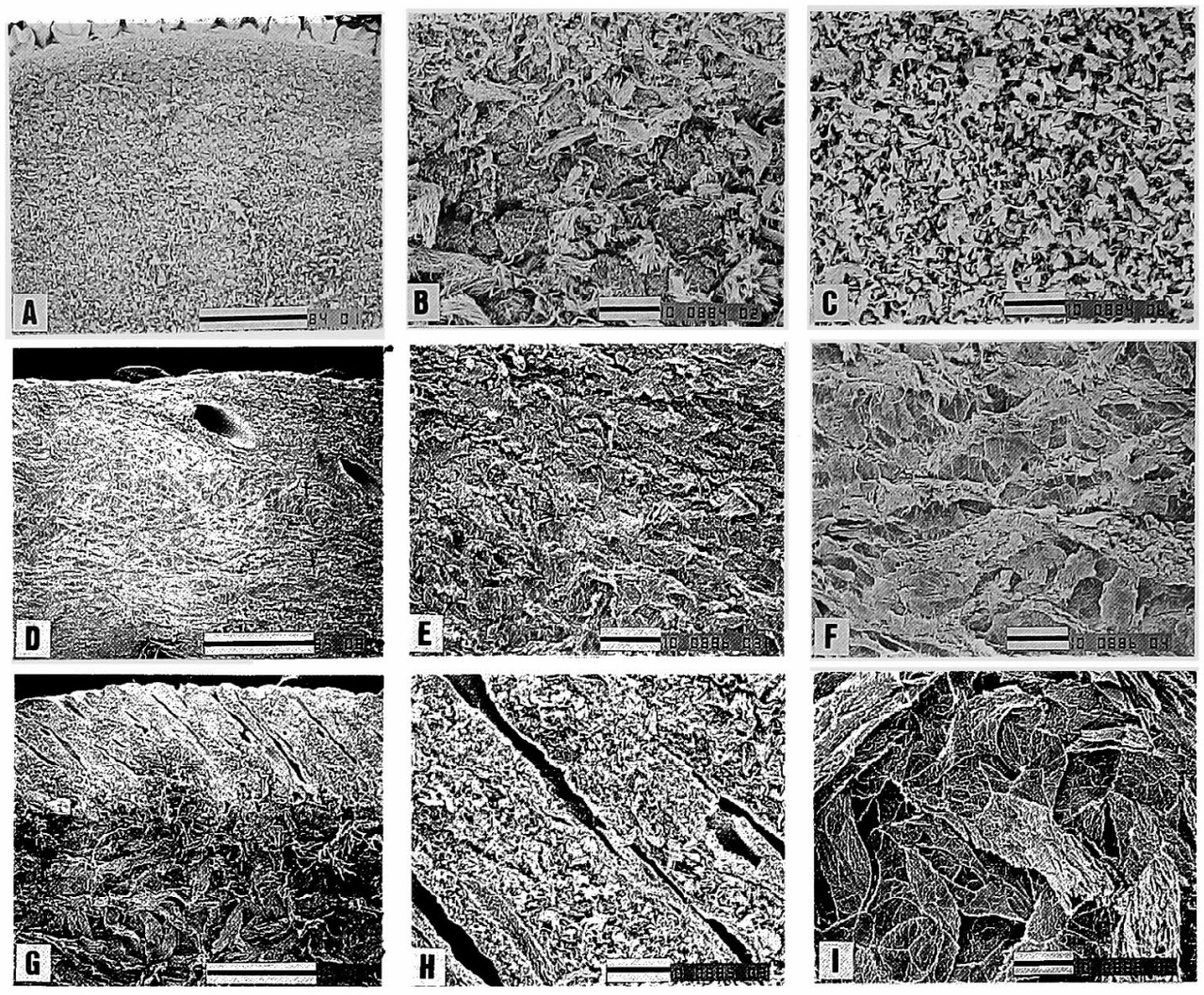

Fig. 1. SEM views of the longitudinal section of shark, pig and bovine skins.

Shark skin (A, B and C), pig skin (D, E and F) and bovine skin (G, H and I).

Upper layer of corium (B, E and $\mathrm{H}$ ) and middle layer of corium (main part of skin, $\mathrm{C}, \mathrm{F}$ and $\mathrm{I}$ ).

The bar in A, D, G indicates $1 \mathrm{~mm}$ and B, C, E, F, H and I indicate $100 \mu \mathrm{m}$.

tion, the data as a whole demonstrated the characteristic feature of the collagen species (Table 1). SC had lower content of Hyp + Pro and higher contents of Met and Val which agreed with other reports ${ }^{12,14}$, and the description of the common feature in amino acid composition of aquatic collagen ${ }^{13,15,22)}$. The peculiar feature of SC was also confirmed on SDSPAGE (Fig. 3). Type I collagen $\alpha 1$ and $\alpha 2$ chains of SC migrated significantly faster than type I collagen $\alpha 1$ and $\alpha 2$ chains of $\mathrm{PC}$ and $\mathrm{BC}$, as previously reported by Kimura et al. ${ }^{12)}$. The migration of $\beta 12$ chain of SC was also faster than those of $\mathrm{PC}$ and $\mathrm{BC}$.

Non-collagenous proteins associated with collagen:
Purified collagen cubes usually contain a small amount of non-collagenous proteins and uronic acid-containing compound, which have been reported to affect the stability of collagens ${ }^{19,25,26)}$. Proteoglycans should be regarded as important, because the large amount of negative charge on proteoglycan molecule can influence the net charge and reactivity of collagen fibers holding it.

Total uronic acid in three kinds of collagen cubes decreased in the order of shark $>$ pig $>$ bovine as shown in Table 2. Only a small amount of uronic acid with $0.05 \mathrm{M}$ Tris- $\mathrm{HCl}$ buffer at $\mathrm{pH} 7(<2 \%)$ and no protein was extracted in this condition. Therefore the majority of uronic acid were associated with collagen. 


\section{Physico-chemical Properties of Shark Skin}

Table 1. Amino acids composition of collagen preparations used

\begin{tabular}{lrrr}
\hline \hline & Shark & Pig & Bovine \\
\hline Hyp & 67 & 86 & 88 \\
Asp & 45 & 49 & 48 \\
Thr & 24 & 18 & 17 \\
Ser & 42 & 38 & 34 \\
Glu & 76 & 79 & 74 \\
Pro & 100 & 125 & 126 \\
Gly & 311 & 312 & 318 \\
Ala & 119 & 109 & 115 \\
1/2Cys & 2 & 2 & 0 \\
Val & 28 & 23 & 25 \\
Met & 15 & 7 & 6 \\
Ile & 20 & 10 & 11 \\
Leu & 29 & 27 & 25 \\
Tyr & 6 & 6 & 5 \\
Phe & 16 & 15 & 14 \\
His & 10 & 6 & 8 \\
Hyl & 12 & 9 & 9 \\
Lys & 25 & 28 & 27 \\
Arg & 52 & 50 & 50 \\
\hline Total & 1,000 & 1,000 & 1,000 \\
\hline
\end{tabular}

residues/1000 amino acid residues

In the three samples extracted with $0.5 \mathrm{M}$ guanidine hydrochloride, small amount of protein and relatively large amount of uronic acid was obtained from $\mathrm{PC}$ and $\mathrm{BC}(13.1 \%$ and $7.0 \%$ of total uronic acid, respectively) and a small amount of uronic acid was obtained from SC (2.4\%). These suggested that uronic acid containing components, proteoglycans in SC are more strongly associated with collagen. The remaining uronic acid after extraction with 0.5 $M$ guanidine hydrochloride decreased in the order of SC $3.1 \mathrm{mg} / \mathrm{g}>\mathrm{PC} 2.7 \mathrm{mg} / \mathrm{g}>\mathrm{BC} 1.8 \mathrm{mg} /$ $\mathrm{g}$. This order coincided with the increasing thickness of the collagen fibrillar bundles observed in SEM. This result agreed with the previous paper ${ }^{1,27)}$ that proteoglycans control the thickness of collagen fibrils in living organisms. It may be that the uronic acid associated with shark collagen affect not only thickness of collagen fibrils but also physico-

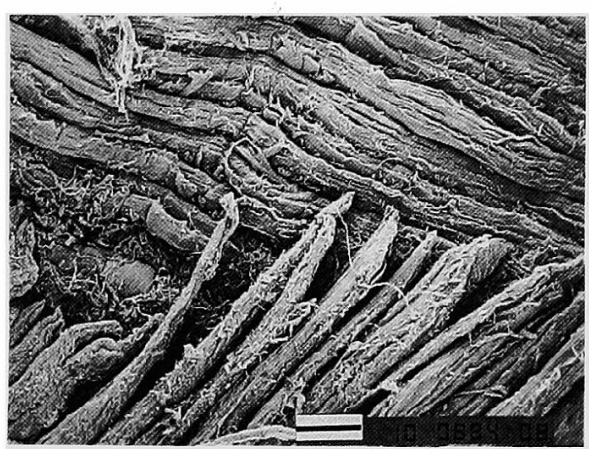

Fig. 2. SEM views of the transverse section of Great Blue Shark skin (upper layer of corium). The Bar is $20 \mu \mathrm{m}$.

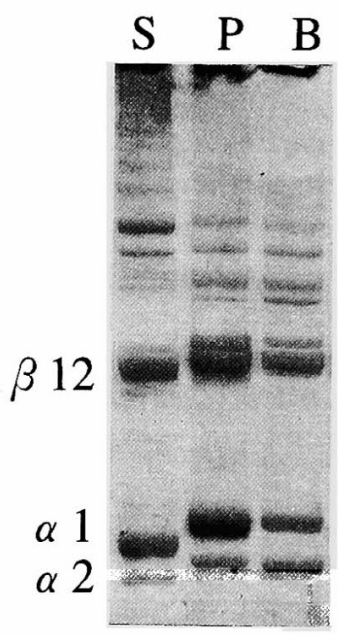

Fig. 3. SDS-PAGE of shark, pig and bovine skin collagens.

S : Shark skin collagen, P : Pig skin collagen, B : Bovine hide collagen.

$\alpha 1$ : Type I collagen $\alpha 1$ chain, $\alpha 2$ : Type I collagen $\alpha 2$ chain, $\beta 12$ : Type I collagen $\beta 12$ chain.

chemical property of collagen.

pH-titration curves :

$\mathrm{pH}$-titration curves were measured on collagen powders, because the cube sample requires an extremely long time to obtain the equilibrium. For the three collagen powders, the combined hydrogen ion in the acidic region was larger than that of combined hydroxyl ion in the alkaline region ${ }^{4)}$ as shown in Fig. 4. The 
YOSHIMURA, HOZAN, CHONAN and SHIRAI

Table 2. Total and extractable uronic acid extractable protein in collagen preparations

\begin{tabular}{|c|c|c|c|c|c|}
\hline & Solvent & $\begin{array}{c}\text { Extracted } \\
\text { protein } \\
(\%)^{* 1}\end{array}$ & $\begin{array}{l}\text { Extracted UA } \\
(\mu \mathrm{g} / \mathrm{g})^{* 1}\end{array}$ & $\begin{array}{c}\text { Extracted UA/ } \\
\text { Total UA } \\
(\%)\end{array}$ & $\begin{array}{l}\text { Total UA } \\
(\mathrm{mg} / \mathrm{g})^{* 1}\end{array}$ \\
\hline \multirow[t]{2}{*}{ Shark } & $0.05 \mathrm{M}$ Tris $-\mathrm{HCl}, \mathrm{pH} 7.0$ & - & 61.9 & 2.0 & 3.1 \\
\hline & $0.5 \mathrm{M} \mathrm{GuHCl}, \mathrm{pH} 7.0$ & 2.8 & 75.6 & 2.4 & \\
\hline \multirow[t]{2}{*}{ Pig } & $0.05 \mathrm{M}$ Tris-HCl, $\mathrm{pH} 7.0$ & - & 37.4 & 1.4 & 2.7 \\
\hline & $0.5 \mathrm{M} \mathrm{GuHCl}, \mathrm{pH} 7.0$ & 3.0 & 353.0 & 13. 1 & \\
\hline \multirow[t]{2}{*}{ Bovine } & $0.05 \mathrm{M}$ Tris-HCl, pH 7.0 & - & 33.5 & 1.8 & 1.8 \\
\hline & $0.5 \mathrm{M} \mathrm{GuHCl}, \mathrm{pH} 7.0$ & 0.1 & 127.6 & 7.0 & \\
\hline
\end{tabular}

*1 : Amounts of extracts are expressed as percentage to collagen on dry weight basis. $\mathrm{UA}$ : uronic acid, $\mathrm{GuHCl}$ : Guanidine hydrochrolide

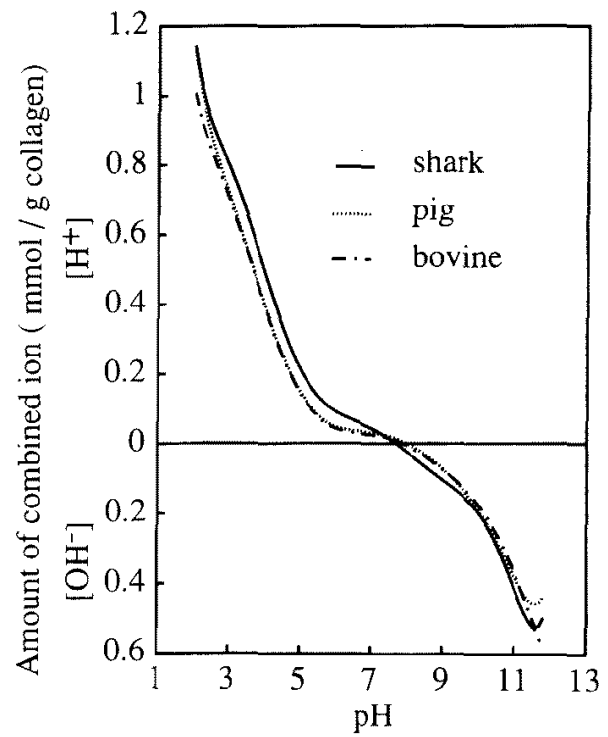

Fig. 4. pH titration curves of shark, pig and bovine skin collagens.

maximum combination of hydrogen ion or hydroxyl ion was attained below $\mathrm{pH} 2.5$ or above $\mathrm{pH} 9.5$, respectively and indicated no difference among collagen species. However, in the $\mathrm{pH}$ region between 2.5 and 9.5 , SP had a significantly larger amount of hydrogen ion or hydroxyl ion compared with PP and BP. In particular at about $\mathrm{pH} 6$, SP exhibited two times larger combination than $\mathrm{BP}$ and PP. This indicated that the reactivity of carboxyl groups in shark skin collagen is very strong in a weak acidic region. In leather tanning, the role of reactivity of carboxyl groups in a weak acidic medium is very important because it provides a large influence on the reactivity of skin collagen with chrome tanning agents. In the $\mathrm{pH}$ region between 8 and 9.5 , the combination of hydroxyl ion was slightly larger in SP. This suggested a stronger reactivity of $\varepsilon$ amino and guanidine groups in shark skin collagen. The stronger reactivity of carboxyl and basic groups in shark skin collagen cannot be simply explained in terms of amino acid compositions (amounts of acidic and basic amino acid residues such as Asp, Glu, Lys and Arg) but also of the finer fiber structure.

As discussed in the earlier section, shark skin collagen holds a larger amount of proteoglycan strongly associated with collagen fibril. In due consideration of this fact, proteoglycan in shark skin collagen may induce the formation of thinner collagen fibrils and fibrillar bundles and consequently increased the reactivity of the carboxyl groups as well as the swelling ability.

\section{Swelling ability :}

Although all the three collagens exhibited a strong swelling in the acidic and alkaline regions in the manner as known ${ }^{5,6,8)}$ (Fig. 5), the swelling of SC was remarkably strongest. It is generally known that with decreasing $\mathrm{pH}$, the swelling of collagen rapidly increases below a critical $\mathrm{pH}^{8)}$. This $\mathrm{pH}$ level is considered to 


\section{Physico-chemical Properties of Shark Skin}

indicate the cohesive force in the collagen fibers and therefore is a gauge to measure the stability of collagen structure. In this experiment, the critical $\mathrm{pH}$ was about 3.5 for $\mathrm{PC}$ and BC. However, for SC, the acid swelling began at $\mathrm{pH} 7$ and increases dramatically below $\mathrm{pH}$ 4.5. Therefore, the acid swelling was more significant in $\mathrm{SC}$ than in $\mathrm{PC}$ and $\mathrm{BC}$. In this $\mathrm{pH}$ region the solubility of collagen was also larger for SC (Fig. 6). As discussed above, this tendency is consistent with the high reactivity of carboxyl groups of shark skin collagen in the acidic region.

Such an acid swelling of shark skin collagen is presumed to be of Donnan type where the swelling is caused by excess positive charge as the result of the reaction between. carboxylate and hydronium ions in the acidic region. This presumption is supported by the fact that the

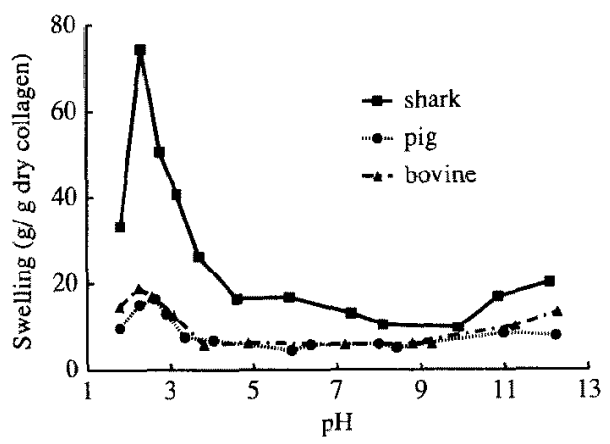

Fig. 5. Swelling of shark, pig and bovine skin collagens at different $\mathrm{pH}$

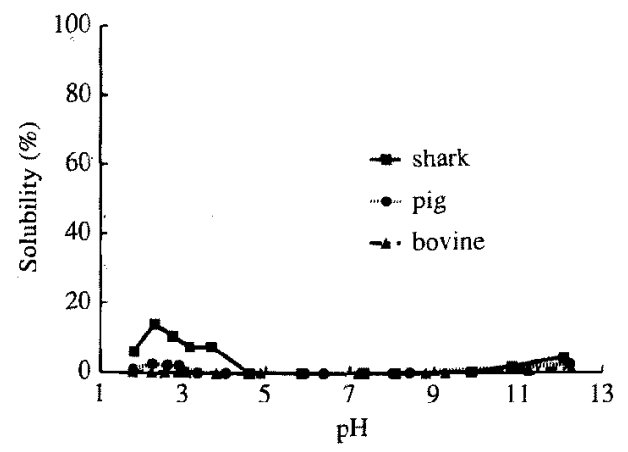

Fig. 6. Solubility of shark, pig and bovine skin collagens at different $\mathrm{pH}$. swelling of $\mathrm{SC}$ was suppressed to the level of $\mathrm{PC}$ and $\mathrm{BC}$ as shown in Fig. 7, when sodium chloride was added at a concentration exceeding $1 \%$ and the balance between positive and negative charges was equalized inside and outside the fibers.

As for $\mathrm{pH}$ titration curves, proteoglycan may increase the reactivity of carboxyl groups on collagen, not only by the direct effect of the negative charge of proteoglycan itself but also by the indirect effect resulting from the decrease in thicknesses of collagen fiber bundle as regulated by proteoglycan.

Denaturation temperature at various $p H$ :

DSC measurements were made to study the denaturation behaviors of three kinds of collagens at various $\mathrm{pH}$ values. DSC curves of all the three kinds of collagens gave the sharpest peak in neutral $\mathrm{pH}$ regions as shown in Fig. 8. For every kind of collagen, DSC curve showed a minor peak or shoulder on a high temperature side of the major peak of endotherm. Such a pattern was most significant at $\mathrm{pH} 12$. This suggested that there are at least two kinds of structural elements having different stability in collagen tissue.

It has been widely known that aquatic collagen has significantly lower denaturation temperature than those of land animals ${ }^{15,17,22,23)}$ Also in the present study, the denaturation

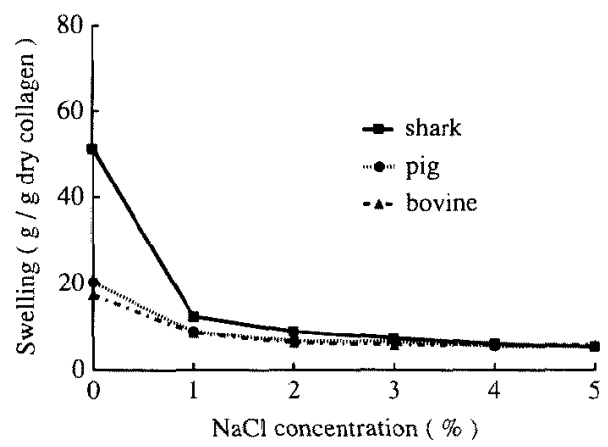

Fig. 7. Acid swelling of shark, pig and bovine skin collagen at different $\mathrm{NaCl}$ concentration. Swelling ability was measured at $\mathrm{NaCl}$ concentration of $0,1,2,3,4$ and $5 \%$ at $\mathrm{pH} 2.8$. 

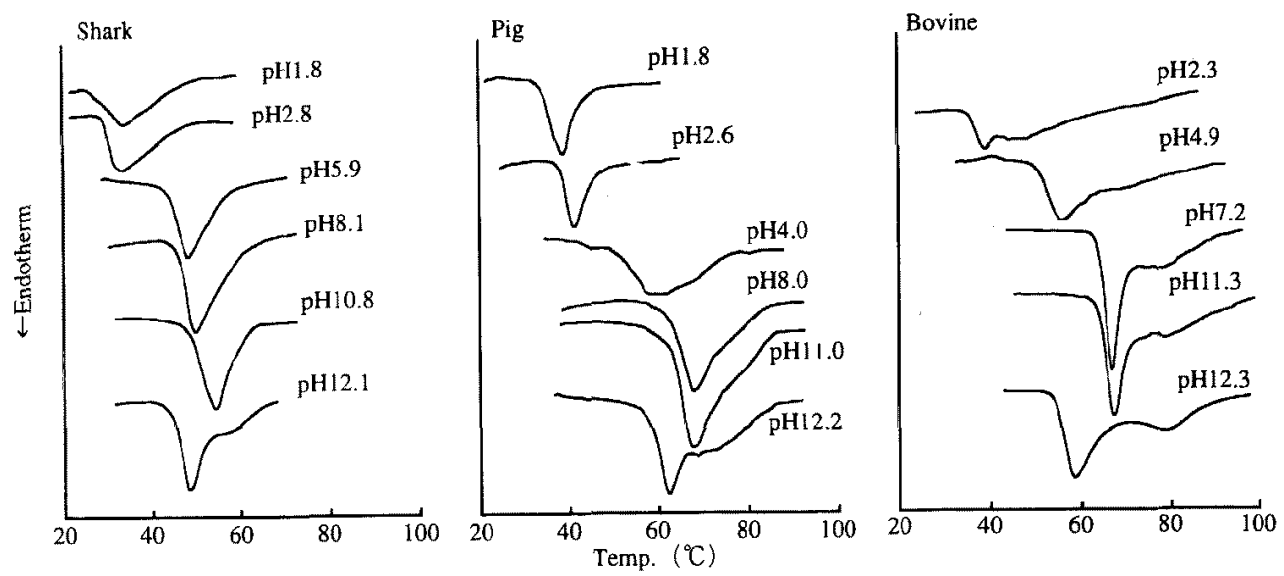

Fig. 8. DSC curves of shark, pig and bovine skin collagens at various $\mathrm{pH}$.

temperature of $\mathrm{SC}$ was lower than of $\mathrm{PC}$ and $\mathrm{BC}$ by about $20^{\circ} \mathrm{C}$. In order to clarify the $\mathrm{pH}$ dependency of denaturation temperature, $\mathrm{Tp}$ values of major peaks were plotted against $\mathrm{pH}$ values, as shown in Fig. 9. In all the three collagens, Tp was inclined to decrease below $\mathrm{pH} 5$ or at about $\mathrm{pH} 12$. This reflected the low stability of fiber structure in this $\mathrm{pH}$ region, presumably due to the increased degree of swelling. However, in a weak alkaline region of $\mathrm{pH} 7-11$, the denaturation temperature of SC showed a $\mathrm{pH}$ dependency different from those of $\mathrm{PC}$ and $\mathrm{BC}$. The denaturation temperature of $\mathrm{PC}$ and $\mathrm{BC}$ showed little change in the region between $\mathrm{pH} 6$ and $\mathrm{pH} 11$ and between $\mathrm{pH} 5$ and $\mathrm{pH} 11$, respectively, while the denaturation temperature of $\mathrm{SC}$ rose by $4^{\circ} \mathrm{C}$ when $\mathrm{pH}$ changed to 4.5 to 11 . In other words, with increased alkalinity, the thermal stability of shark skin collagen was inclined to increase to a larger extent than those of the other two collagens. The reason for this could not be explained. However, it may be presumed that shark skin collagen contains a larger amount of interchain crosslinkages such as aldimine bonds that are stabilized in the alkaline medium. Such an effect of alkali on shark skin collagen should be regarded as important from the practical view point of shark skin

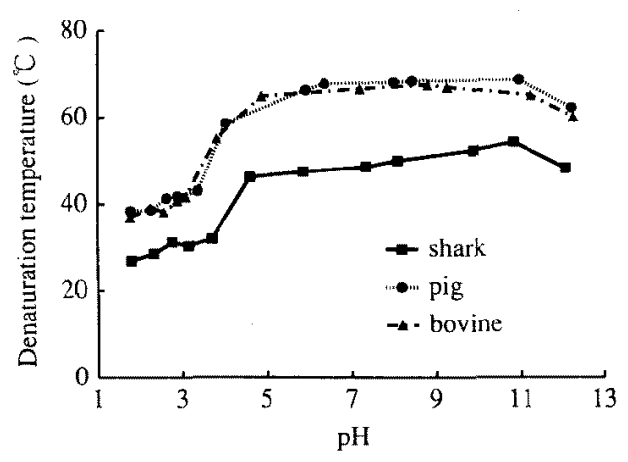

Fig. 9. Denaturation temperature (Tp: peak top temperature of DSC curve) of shark, pig and bovine collagens at different $\mathrm{pH}$.

technology, since the alkaline treatment is always used in the unhairing process of leather manufacture and also employed in collagen purification in gelatin and collagen industries.

\section{Conclusions}

Shark skin collagen has several features of physico-chemical properties, in comparison with those of pig and bovine skins. Shark skin tissue is constituted of finer collagen fibrillar bundles and contains a larger amount of uronic acid-containing components (proteoglycans) strongly associated with collagen. The amount of combined hydrogen or hydrox- 
$\mathrm{yl}$ ions of SP was found to be significantly large in the region of $\mathrm{pH} 2.5-9.5$. Furthermore, the swelling of $\mathrm{SC}$ was remarkably large. In the acidic region, particularly the swelling began to occur at $\mathrm{pH} 7$ and increased sharply below $\mathrm{pH} 4.5$.

Summarizing the described results, it is concluded that the peculiarity in physico-chemical behavior of shark skin collagen is at least partially attributed to its fine fiber structure and higher content of proteoglycan associated collagen. These features probably make shark skin collagen more susceptible to the action of acid and alkali and more sensitive to the swelling power. Thus shark skin collagen demonstrated a more sensitive reactivity of carboxyl groups in the acidic $\mathrm{pH}$ region and of basic groups in the alkaline $\mathrm{pH}$ region. Such a sensitive reactivity of functional groups in shark skin collagen was reflected in the remarkable swelling ability.

Denaturation temperature of SC was lower than those of PC and $\mathrm{BC}$ as generally known. Denaturation temperature of all the three collagens remarkably decreased in the $\mathrm{pH}$ region below 5 or near 12. This instability of collagen structure in relatively strong acidic or alkaline medium is probably attributed to the increased swelling of fiber in those $\mathrm{pH}$ regions. In spite of this, SC showed an increased stability in the alkaline region below $\mathrm{pH} 12$. This suggested that a large amount of alkali-stabilizable bonds of interchain nature such as aldimine cross-linkage are involved in shark skin collagen fiber structure.

\section{References}

1) Anderson JC, Labedz RI, Kewley MA. The Effect of Bovine Tendon Glycoprotein on the Formation of Fibrils from Collagen Solution. Biochem. J., 168 : 345-351. 1977.

2) Bailey AJ. Collagen - Nature's Framework in the Medical, Food and Leather Industries. J. Soc. Leather Technol. Chem., 76 : 111-127. 1992.

3) Bitter T. Muir H. A Modified Uronic Acid Carbazole Reaction. Anal. Biochem., 4:330-
334. 1964.

4) Bowes JH, Kenten RH. The Amino-acid Compositon and Titration Curve of Collagen. Biochem. J., $43:$ 358-365. 1948.

5) Bowes JH, Kenten RH. The Effect of Alkalis on Collagen. Biochem. J., 43 : 365-372. 1948.

6) Cassel JM, McKenna E. Swelling of Collagen and Modified Collagen. J. Am. Leather Chem. Assoc., 49:553-574. 1954.

7) Chonan $Y$. The Changes of Collagen by Chemical Modification. Hikaku Kagaku, 37 : 141-154. 1991.

8) Gustavson $\mathrm{KH}$. The Chemistry and Reactivity of Collagen. 155-160. Academic Press. New York. 1956.

9) Hayashi $T$, Nagai $Y$. Separation of the $\alpha$ Chains of Type I and III collagens by SDSPolyacrylamide Gel Electrophoresis. J. Biochem., 86: 453-459. 1979.

10) Huc A. Collagen Biomaterials Characteristics and Applications. J. Am. Leather Chem. Assoc., 80: 195-212. 1985.

11) Itzhaki RF, Gi11 DM. A Micro-biuret method for estimating proteins. Anal. Biochem., 9 : 401-410. 1964.

12) Kimura S, Kamimura T, Takema Y, Kubota M. Lower Vertebrate Collagen Evidence for Type I-like Collagen in the Skin of Lamprey and Shark. Biochim. Biophys. Acta, 669 : 251-257. 1981.

13) Kimura S. Molecular Species of Collagen. Hikaku Kagaku, $29: 55-72.1983$.

14) Kubota M, Kimura S. Skin Collagen of the Great Blue Shark. Nippon Suisan Gakkaishi, $33: 338-342.1967$.

15) Kubota M. Basic Studies on Collagens - Mainly upon Collagens of Aquatic Animals. Hikaku Kagaku, 24 : 73-95. 1978.

16) Laemmli UK. Cleavage of Structural Proteins during the Assembly of the Head of Bacteriophage T4. Nature, $227: 680-685.1970$.

17) McClain PE, Wiley E. Differential Scanning Calorimeter Studies of the Thermal Transitions of Collagen: Implications on Structure and Stability. J. Biol. Chem., 247 : 692-697. 1972.

18) Miyata T. Application of Scleroproteins as a Biomedical Material. Hikaku Kagaku, 28: 7590. 1982.

19) Nomura Y. Takahashi K, Shirai K. Features of Collagen Matrix Reconstructed with Proteodermatan Sulfate from Pigskin Insoluble Collagen. Agric. Biol. Chem., 53: 939-948. 1989.

20) Ohtani 0 . Three-dimensional Organization of 


\title{
YOSHIMURA, HOZAN, CHONAN and SHIRAI
}

the Connective Tissue Fibers of the Human Pancreas: A Scanning Electron Microscopic Study of $\mathrm{NaOH}$ Teated-Tissues. Arch. Histol. Jap., $50: 557-566.1987$.

21) Ohtani O. Three-Dimensional Organization of the Collagen Fibrillar Framework of the Human and Rat Livers. Arch. Histol. Cytol., 51 : 473-488. 1988.

22) Piez KA, Gross J. The Amino Acid Composition of Some Fish Collagens: The Relation between Composition and Structure. J. Biol. Chem., $235:$ 995-998. 1960.

23) Privalov PL, Tikutopulo EI. Thermal Conformational Transformation of Tropocollagen. 1. Calorimetric Study. Biopoly mers, 9 : 127-139. 1970.

24) Shirai K, Ikenoue I, Wada K, Kawamura A. Properties of Pigskin Insoluble Collagen. Jpn. J. Zootech. Sci., $50:$ 217-222. 1979.
25) Shirai K, Wada K. Changes in Properties of Pigskin Collagen by Liming. Jpn. J. Zootech. Sci., 52 : 749-756. 1981.

26) Shirai K, Wada K. Über die Struktur von Schweinehautkollagen. Leder, 34 : 197-201. 1983.

27) Tajima S, Nagai Y. Isolation and Partial Characterization of Collagen Fibrils, Fibers and Fiber-Bundles from Insoluble Calf Dermis. Conn. Tiss. Res., $7: 157-163.1980$.

28) Takahashi $K$, Yoshimura $K$, Shirai $K$, Wada $K$. Thermal Behavior of Reconstituted Collagen Fibrils. Jpn. J. Zootech. Sci., 57 : 497-502. 1986.

29) Takahashi T. Some Fundamental Knowledges on Shark Leather Manufacture. Hikaku Kagaku, 3 : 59-78. 1957.

30) Toyoda H, Chonan Y. Chemical Modification of Collagen and Gelatin. Hikaku Kagaku, 30 : 3-21. 1984.

\section{ブタ，ウシ皮との比較におけるサメ皮コラーゲンの理化学的性質}

\author{
吉村圭司・宝山大喜・長南康正 · 白井邦郎* \\ 東京都立皮革技術センター，東京都墨田区 131 \\ *東京農工大学農学部，府中市 183
}

\begin{abstract}
サメ皮コラーゲンの構造，官能基の反応性，膨洞性及び示差走查熱量計による熱的性質についてブタ， ウシのコラーゲンと比較した．走查型電子顕微鏡による観察に扔いては，サメ皮はフタ，ウシと比较し て, 皮の主要部分を占める真皮中間㒶のコラーゲン細線維束が践で細いことに特徽があった。コラーゲ ン試料中の全ウロン酸成分すなわちプロテオグリカン量は，サメ皮コラーゲンが最も多いが，抽出され る量は最す少なく、サメ皮コラーゲンはプロテオグリカンと強く結合していることが示唆された。 $\mathrm{pH}$ 滴定曲線から, 水素イオンまたは水酸イオンの最大結合量について 3 種のコラーゲン問に差は認められ ないが，サメ皮コラーゲンは中性加ら弱酸性領域での水素イオン結合量が他のコラーゲンに比較して顕 著に多いことが認められた。路潤度については，サメ皮コラーゲンの膨㵎性が大きく，特に酸膨潤が大 きいことが認められた。種々の $\mathrm{pH}$ における熱変性温度は,ブタ及びウシ皮コラーゲン間に差はなく， サメ皮コラーゲンは顕著に低かった。 しかし，サメ皮コラーゲンはアルカリ性で变性温度が上昇する傾 向が認められた。
\end{abstract}

日畜会報，67 (5)：445-454，1996 